\title{
Efficient In Vitro Propagation Protocol of Swertia chirayita (Roxb. ex Fleming) Karsten: A Critically Endangered Medicinal Plant
}

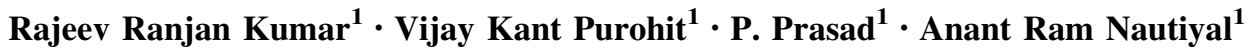

Received: 28 September 2016/Revised: 14 July 2017/Accepted: 23 March 2018/Published online: 10 April 2018 (C) The Author(s) 2018

\begin{abstract}
Leaf explants of critically endangered medicinal plant Swertia chirayita were cultured in Murashige and Skoog medium fortified with various concentrations of 2,4Diclorophenoxyacetic acid (2,4-D), 6-Benzylaminopurine (BAP) and Gibberalic acid (GA3). The best callus induction was obtained in 2,4-D $(15.0 \mu \mathrm{M})$ after 60 days of culture period. After 30 days of first subculture, maximum 32 microshoots were formed in a lump of callus in combination of BAP $(10.0 \mu \mathrm{M})$ with GA3 $(5.0 \mu \mathrm{M})$. On the other hand maximum 25 microshoots were formed from a lump of callus in BAP $(5.0 \mu \mathrm{M})$ used alone. The multiple shoots developed in combination of BAP with GA3 were found poor/thin in comparison to BAP alone. Therefore, the further subculture was conducted in $\operatorname{BAP}(5.0 \mu \mathrm{M})$ and approximately 210 microshoots per lump of callus were obtained within 3-4 months of culture. Root induction was observed in all microshoots cultured in various concentrations of auxins (Indole-3-butyric acid, IBA and Indole-3acetic acid, IAA) after 45 days of culture, however, the higher mean number of roots (50) per microshoot were formed in IBA $(5.0 \mu \mathrm{M})$. After a month, well rooted plantlets were successfully transplanted and established $(58.70 \%)$ in mixture of soil, sand and FYM (2:1:1) under partially shade (75\% agro shade net) condition in nursery at Pothibasa (2200 m a.s.l.).
\end{abstract}

Keywords Swertia chirayita - Medicinal herb . Critically endangered $\cdot$ In vitro propagation

Vijay Kant Purohit

vijaykantpurohit@rediffmail.com

1 High Altitude Plant Physiology Research Centre (HAPPRC), H.N.B. Garhwal University (A Central University), Srinagar, Garhwal, Uttarakhand 246 174, India
Swertia chirayita is a well-known medicinal plant found growing in Himalayan region. It is used as herbal medicine for various health ailments including liver disorder, malaria, diabetes, skin disease and fever. Owing to the multiple uses of the species, its market demand in pharmaceutical industries has been increased considerably. To fulfil the increasing pharmaceutical demand of the species in indigenous and world market, regular extensive collection of the immature as well as mature plants of $S$. chirayita from natural habitats is leading day by day to declining populations of the species that may ultimately raise chances of its extinction in near future [1]. On the other hand poor seed germination and lack of natural vegetative propagation, there is an urgent need to develop reliable and applicable propagation and conservation measures of the species. Therefore, the aim of present study was to develop an efficient in vitro propagation protocol for this valuable medicinal plant using a leaf as explants.

Mature plants of $S$. chirayita were collected from the wild population at Pangarbasa (Mandal, Gopeshwar, Chamoli; altitude 2300-2480 m a.s.1., Uttarakhand, India) in the month of August and established in plastic pots kept in nursery at High Altitude Plant Physiology Research Centre (HAPPRC; Fig. 1a, $550 \mathrm{~m}$ a.s.l.). The leaf explants collected from the nursery established plants were surface disinfected using detergent solution (Tween 20, two drop $\mathrm{v} / \mathrm{v} ; 10 \mathrm{~min}$ ) and washed under running tap water for $15 \mathrm{~min}$. Subsequently, the leaf explants were repeatedly rinsed in distilled water and then treated with a solution containing systematic fungicide (Bavistin, $0.1 \%$, w/v; $20 \mathrm{~min}$ ) followed by sodium hypochlorite (chlorine 5\%) for $5 \mathrm{~min}$ and finally rinsed with sterile distilled water under laminar air flow cabinet. After completing disinfection process the disinfected leaf explants $(1 \mathrm{~cm}$ long) were inoculated in $250 \mathrm{ml}$ Erlenmeyer flasks containing 


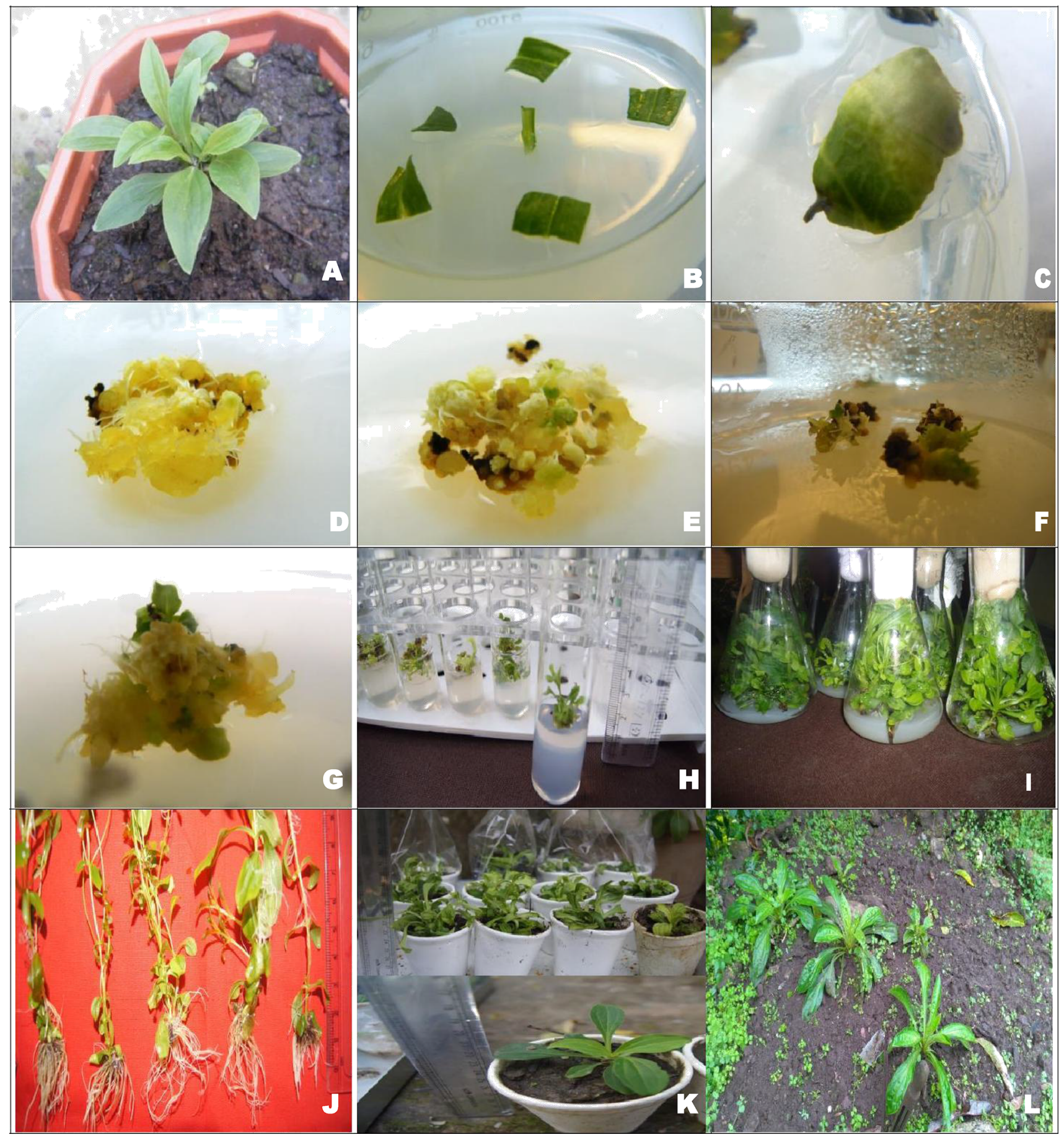

Fig. 1 Different stages of in vitro propagation of $S$. chirayita. Nursery established mature plants collected from wild (a), establishment of leaf explants in culture media (b), swelling in leaf explants after 7 days (c), conversion of leaf explants in green yellow callus after 60 days (d and e), initiation of microshoots from calli after 15 days ( $\mathbf{f}$ and $\mathbf{g}$ ), different stages of shoot development and growth

Murashige and Skoog (MS) medium with $0.8 \%(\mathrm{w} / \mathrm{v})$, agar, $3.0 \%(\mathrm{w} / \mathrm{v})$ sucrose and various concentrations of 2,4-Diclorophenoxyacetic acid (2,4-D) and 6-Benzylaminopurine (BAP). Explants cultured on medium without PGRs served after 30 days (h and $\mathbf{i}$ ), root formation in microshoots after 45 days (j), transfer of rooted microshoots for hardening in mixture of soil, sand and FYM $(2: 1: 1 ; \mathbf{k})$, and well grown plants in nursery/field condition after 40 days (l)

as control. Each treatment consisted of 24 explants and all the treatments were repeated twice. Data on callus, microshoots and root formation were recorded regularly. For root induction, microshoots $(3.0-4.0 \mathrm{~cm}$ height with 4 
Table 1 Effect of MS medium supplemented with different concentrations of BAP and GA3 on in vitro multiple shoot formation from callus of S. chirayita

\begin{tabular}{lllll}
\hline PGRs & Concentrations $(\mu \mathrm{M})$ & \% Response per callus & No. of shoots per callus (mean \pm SE) & Length of shoots $(\mathrm{cm})(\mathrm{mean} \pm \mathrm{SE})$ \\
\hline BAP & 3.0 & 100 & $5.33 \pm 3.21$ & $1.01 \pm 0.20$ \\
& 5.0 & 100 & $25.00 \pm 8.00$ & $3.99 \pm 0.33$ \\
& 8.0 & 100 & $4.00 \pm 1.00$ & $1.27 \pm 0.32$ \\
& 10.0 & 100 & $13.33 \pm 3.51$ & $0.77 \pm 0.10$ \\
& 12.0 & 100 & $12.33 \pm 2.51$ & $0.63 \pm 0.1$ \\
& 14.0 & 100 & $9.00 \pm 1.00$ & $0.29 \pm 0.03$ \\
& 16.0 & 100 & $6.00 \pm 1.00$ & $2.33 \pm 0.57$ \\
BAP + GA3 & $3.0+1.0$ & 100 & $0.56 \pm 0.20$ & $3.00 \pm 1.00$ \\
& $5.0+3.0$ & 100 & $0.63 \pm 0.15$ & $4.33 \pm 0.57$ \\
& $8.0+4.0$ & 100 & $1.33 \pm 0.15$ & $6.99 \pm 1.20$ \\
& $10.0+5.0$ & 100 & $32.66 \pm 6.42$ & $4.00 \pm 1.00$ \\
& $12.0+7.0$ & 100 & $1.93 \pm 0.05$ & $2.00 \pm 1.00$ \\
Control & $14.0+9.0$ & 100 & 0.660 .20 & $2.00 \pm 1.00$ \\
LSD $(P<0.05)$ & - & 100 & $0.46 \pm 0.05$ & $10 \pm 1.00$ \\
\hline
\end{tabular}

All values are an average of 9 explants (lump of callus). The multiple shoot formation experiment was repeated thrice

Table 2 Effect of MS medium containing different concentrations of auxins (IBA and IAA) on rooting of microshoots of $S$. chirayita

\begin{tabular}{lllllll}
\hline Auxins & $\begin{array}{l}\text { Concentrations } \\
(\mu \mathrm{M})\end{array}$ & $\begin{array}{l}\text { Rooting } \\
(\%)\end{array}$ & $\begin{array}{l}\text { Length of microshoots used for } \\
\text { rooting }(\text { mean } \pm \mathrm{SE})\end{array}$ & $\begin{array}{l}\text { No. of roots/micros hoot } \\
(\mathrm{mean} \pm \mathrm{SE})\end{array}$ & $\begin{array}{l}\text { Root length }(\mathrm{cm}) \\
(\mathrm{mean} \pm \mathrm{SE})\end{array}$ & $\begin{array}{l}\text { Root diameter }(\mathrm{mm}) \\
(\mathrm{mean} \pm \mathrm{SE})\end{array}$ \\
\hline IBA & 1.0 & 100 & $3.16 \pm 0.28$ & $26.66 \pm 11.54$ & $2.88 \pm 0.25$ & $1.08 \pm 0.30$ \\
& 3.0 & 100 & $4.16 \pm 2.08$ & $30.00 \pm 17.32$ & $2.76 \pm 0.90$ & $0.94 \pm 0.19$ \\
& 5.0 & 100 & $3.16 \pm 1.25$ & $50.00 \pm 10.00$ & $2.16 \pm 0.76$ & $0.86 \pm 0.45$ \\
& 10.0 & 100 & $4.66 \pm 2.51$ & $41.00 \pm 3.60$ & $2.33 \pm 0.92$ & $1.41 \pm 0.20$ \\
& 15.0 & 100 & $4.66 \pm 1.52$ & $33.33 \pm 5.77$ & $2.58 \pm 0.13$ & $1.88 \pm 0.66$ \\
IAA & 1.0 & 100 & $4.66 \pm 1.52$ & $28.33 \pm 10.40$ & $2.34 \pm 1.14$ & $0.91 \pm 0.20$ \\
& 3.0 & 100 & $2.66 \pm 0.28$ & $20.66 \pm 10.06$ & $1.91 \pm 0.89$ & $0.65 \pm 0.14$ \\
& 5.0 & 100 & $3.33 \pm 0.57$ & $22.00 \pm 8.00$ & $3.22 \pm 1.09$ & $2.66 \pm 2.94$ \\
& 10.0 & 100 & $4.00 \pm 1.00$ & $23.33 \pm 4.72$ & $3.52 \pm 0.91$ & $2.67 \pm 1.64$ \\
Control & - & 100 & $4.66 \pm 1.15$ & $28.00 \pm 11.53$ & $3.06 \pm 1.59$ & $1.44 \pm 0.85$ \\
LSD $(P=0.0$ & 100 & $4.66 \pm 2.88$ & $23.66 \pm 4.16$ & $2.49 \pm 0.44$ & $1.01 \pm 0.30$ \\
\hline
\end{tabular}

Data are an average of 24 microshoots

or 5 leaflets; Fig. 1j) excised from the bunch of multiple shoots (Fig. 1i) were cultured on different concentrations of auxins (Indole-3-butyric acid, IBA and Indole-3-acetic acid, IAA). The well rooted microshoots were washed for removal of agar and transferred to thermocol cup containing mixture of soil, sand and Farm Yard Manure (FYM, 2:1:1) and covered with polyethylene bags. The covered plantlets kept inside greenhouse condition for hardening and after 15 days the polyethylene cover were removed.
Then the acclimatized plants were shifted to nursery conditions with partial shade ( $70 \%$ agro shade net) because the natural population of the plants mostly found in shady and sloppy areas. The data were recorded, compared and least significant difference was calculated following the published methods of Snedecor and Cochran [2].

Surface disinfected leaf explants (Fig. 1b) were inoculated in Murashige and Skoog (MS) medium containing various concentrations of 2,4-Diclorophenoxyacetic acid 
Table 3 Establishment and growth of in vitro raised plants of $S$. chirayita under two microclimatic conditions (open and Thatch) after three months of field transfer

\begin{tabular}{|c|c|c|c|c|c|c|c|c|c|}
\hline \multirow{2}{*}{$\begin{array}{l}\text { Microclimatic } \\
\text { condition }\end{array}$} & \multirow{2}{*}{$\begin{array}{l}\text { Survival } \\
(\%)\end{array}$} & \multicolumn{8}{|c|}{ Growth parameters } \\
\hline & & $\begin{array}{l}\text { Plant height } \\
(\mathrm{cm}) \\
(\text { mean } \pm \mathrm{SE})\end{array}$ & $\begin{array}{l}\text { No. of leaf } \\
\text { (mean } \pm S \\
\text { E) }\end{array}$ & $\begin{array}{l}\text { Leaf length } \\
(\mathrm{cm}) \\
(\text { mean } \pm \mathrm{SE})\end{array}$ & $\begin{array}{l}\text { Leaf area } \\
\left(\mathrm{cm}^{2)}\right. \\
(\text { mean } \pm \mathrm{SE})\end{array}$ & $\begin{array}{l}\text { No. of roots } \\
( \pm \mathrm{SE})\end{array}$ & $\begin{array}{l}\text { Root length } \\
(\mathrm{cm}) \\
(\text { mean } \pm \mathrm{SE})\end{array}$ & $\begin{array}{l}\text { Root diam } \\
(\mathrm{mm}) \\
(\text { mean } \pm \mathrm{SE})\end{array}$ & $\begin{array}{l}\text { Collar diam } \\
(\mathrm{mm}) \\
(\text { mean } \pm \mathrm{SE})\end{array}$ \\
\hline Open & 50.00 & $6.39 \pm 3.46$ & $14.0 \pm 5.59$ & $7.61 \pm 3.39$ & $2.12 \pm 0.55$ & $78.75 \pm 26.57$ & $5.14 \pm 0.45$ & $2.27 \pm 0.20$ & $2.23 \pm 0.39$ \\
\hline $\begin{array}{l}\text { Partially shade } \\
\text { (70\% agro } \\
\text { shade net) }\end{array}$ & 58.70 & $11.14 \pm 1.41$ & $15.0 \pm 1.41$ & $15.26 \pm 1.41$ & $2.15 \pm 1.42$ & $90.00 \pm 14.14$ & $6.60 \pm 1.49$ & $0.33 \pm 0.01$ & $2.82 \pm 0.77$ \\
\hline $\operatorname{LSD}(P<0.05)$ & & 4.91 & 0.9 & 8.2 & 0.32 & 11.20 & 0.45 & 2.10 & 0.62 \\
\hline
\end{tabular}

Collar diameter is $0.5 \mathrm{~cm}$ above the ground. Data are an average of 24 plants

(2,4-D). After 7 days of culture the explants were swell (Fig. 1c) and formation of green yellow callus was observed in 15 and $10 \mu \mathrm{M}$ 2, 4-D. However, $15 \mu \mathrm{M}$ 2, 4-D was found to be the best in callus formation after 60 days of culture (Fig. 1d, e), while a report of other study showed combination of 2,4-D and 6-Benzylaminopurine (BAP) was best in callus induction [3]. In the view of producing somatic embryos and microshoots, the lump of healthy and yellowish callus was transferred in same medium supplemented with different concentration of BAP and GA3 in combination or alone. MS medium supplemented with BAP $(10 \mu \mathrm{M})$ and GA3 $(5 \mu \mathrm{M})$ was effective in multiple shoot induction $(32.66 \pm 6.42)$ per callus (Fig. 1f, g), however the shoots were thin and long $(6.00 \pm 1.20 \mathrm{~cm}$, Table 1, Fig. 1h). 6-Benzylaminopurine (BAP, $5.0 \mu \mathrm{M}$ ) used in alone produce shortest $(3.99 \pm 0.33 \mathrm{~cm})$ and healthy microshoots $(25.00 \pm 8.00)$ per callus, Table 1 , Fig. 1i). The least significance difference $(P<0.05)$ revealed that BAP $(10 \mu \mathrm{M})$ in combination with GA3 $(5 \mu \mathrm{M})$ was highly significant among all the treatments (Table 1). Contradictory to this study, combination of BAP and Kinetin was produced maximum shoot in S. chirayita [4]. In earlier studies GA3 had also been found helpful for in vitro shoot regeneration and induction of shoot buds $[5,6]$. This happen due to the GA3 can act as a replacement for auxin in shoot induction, and thus a ratio of cytokininGA3 may be decisive for differentiation in certain plant tissues [7]. In another study, addition of GA3 with BAP also produced thin and long shoots in Quercus leucotrichophora and Q. glauca [8] and better multiple shoot differentiation from lump of callus in Hippophae rhamnoides [9]. 6-Benzylaminopurine (BAP) used without addition of other PGRs also produce high number of shoots which are healthy and better for further growth. The same results found in in vitro propagation of Valeriana wallichii [10]. The higher concentration of both PGRs used in this study showed decreased multiple shoot formation. 6-benzyl adenine (BA), its riboside and nucleotides are naturally occurring cytokinins in plant tissues and are relatively stable in comparison to other cytokinins [11].

The rooting of microshoots excised from multiplying culture was conducted in MS medium containing different concentrations of auxins (IBA and IAA). The $100 \%$ rooting was observed in all microshoots tested for root formation even in control treatment. However, the MS medium containing $5 \mu \mathrm{M}$ IBA produce maximum number of roots $(50.00 \pm 10.00)$ per microshoots (Table 1) in comparison to $15 \mu \mathrm{M}$ IAA $(28.00 \pm 11.53$ roots per microshoots, Table 1 and Fig. 1j) without basal callus formation after 45 days of culture. In the existence $\alpha$-Naphthalene acetic acid (NAA) huge callus formation was found at the base of rooted microshoots. Rooting with basal callus formation is not desirable as it adversely affects the survival of plantlets during the hardening or in the field [12]. Acclimatization is primarily intended for restoring stress resistance and autotrophic competence (Table 2).

The well rooted plantlets were transferred to mixture of soil, sand and FYM (2:1:1) and kept inside the greenhouse condition $\left(25{ }^{\circ} \mathrm{C}\right.$, temperature and $80 \%$ humidity) for 30 days (Fig. 1k). Further, the 30 days old acclimatized plantlets were transferred to nursery at Pothibasa (2200 m a.s.l.) and planted in partially shade (70\% agro shade net) condition. After three months of nursery/field transfer the maximum $58.70 \%$ survival of the plants were recorded with maximum plant height $(11.14 \pm 1.41 \mathrm{~cm})$ and number of leaves $(15.0 \pm 1.41$ per plant, Table 3 and Fig. 11).

The conservation of highly demanded and rare, endangered and threaten (RET) status medicinal and aromatic plants is necessary for the use of future generation. The in vitro propagation method is only viable substitute for propagation using any parts of plants as explants and also useful supplement or alternative to the conventional propagation method of seed germination. However, there are number of reports available on in vitro propagation of $S$. chirayita [13, 14], but the per cent survival of plants in nursery/field condition is a matter of great concern. The 
results of the present study showed that the leaf explants were good source for in vitro propagation of $S$. chirayita via callus induction followed by multiple shoot formation, rooting of individual microshoots and successful transplantation of the plantlets in nursery/field condition. The MS medium containing BAP $(10.0 \mu \mathrm{M})$ in combination with GA $3(5.0 \mu \mathrm{M})$ and BAP $(5.0 \mu \mathrm{M})$ alone were highly useful for formation and development of microshoots and IBA $(5 \mu \mathrm{M})$ for root induction. The partially shade $(75 \%$ agro shade net) condition is also useful/suitable for nursery/field establishment of in vitro raised plants of $S$. chirayita.

Acknowledgements The authors gratefully acknowledge the Uttarakhand State Biotechnology Department (USBD), Govt. of Uttarakhand for financial support and Director, High Altitude Plant Physiology Research Centre (HAPPRC) for providing experimental facilities.

Open Access This article is distributed under the terms of the Creative Commons Attribution 4.0 International License ( http://creativecommons.org/licenses/by/4.0/), which permits unrestricted use, distribution, and reproduction in any medium, provided you give appropriate credit to the original author(s) and the source, provide a link to the Creative Commons license, and indicate if changes were made.

\section{References}

1. Purohit VK, Bahuguna YM, Tiwari D, Tiwari A, Andola HC, Negi JS, Chauhan RS (2013) Swertia chirayita (Roxb. ex Fleming) on the verge of extinction in the Himalayan region. Curr Sci 104(2):161-162

2. Snedecor GW, Cochran WG (1967) Statistical methods. Oxford and IBH Publishing Co., New Delhi
3. Pant M, Bisht P, Gusain MP (2012) In vitro propagation through root-derived callus culture of Swertia chirata Buch.-Ham. ex Wall. Afr J Biotechnol 11(29):7408-7416

4. Balaraju K, Agastian P, Ignacimuthu S (2009) Micropropagation of Swertia chirata Buch.-Hams. ex Wall.: a critically endangered medicinal herb. Acta Physiol Plant 31:487-494

5. Chakrabarty D, Mandal AKA, Datta SK (2000) Retrieval of new coloured chrysanthemum through organogenesis from sectorial chimera. Curr Sci 78:1060-1061

6. Mishra P, Datta SK (2001) Direct differentiation of shoot buds in leaf segments of white marigold (Tagetes erecta L.). In vitro Cell Dev Biol Plant 37:466-470

7. Sekioka TA, Tanaka JS (1981) Differentiation in callus culture of cucumber (Cumumis sativus L.). Hort Sci 16:451

8. Purohit VK, Tamta S, Chandra S, Vyas P, Palni LMS, Nandi SK (2002) In vitro multiplication of Quercus leucotrichophora and Q. glauca Thunb.: important Himalayan oaks. Plant Cell Tissue Organ Cult 69:241-245

9. Purohit VK, Phondani PC, Maikhuri RK, Niladri Bag, Prasad P, Nautiyal AR, Palni LMS (2009) In vitro propagation of Hippophae rhamnoides $\mathrm{L}$. from hypocotyle explants. Nat Acad Sci Lett 32(5\&6):163-168

10. Singh S, Purohit VK, Prasad P, Nautiyal AR (2015) Micropropagation of Valeriana wallichii DC. (Indian Valerian) through nodes. Ind J Biotechnol 14:127-130

11. Letham DS, Palni LMS, Tao GQ, Gollnow BI, Bates CM (1983) Regulators of cell division in plant tissues. XXIX. The activities of cytokinin glucosides and alanine conjugates in cytokinin bioassays. Plant Growth Regul 2:103-115

12. Kumar V, Chandra S (2013) Efficient regeneration and antioxidant activity of the endangered species Swertia chirayita. Int $\mathbf{J}$ Bio Sci 4(4):823-833

13. Balaraju K, Saravanan S, Agastian P, Ignacimuthu S (2011) A rapid system for micropropagation of Swertia chirata Buch.Ham. ex Wall.: an endangered medicinal herb via direct somatic embryogenesis. Acta Physiol Plant 33(4):1123-1133

14. Sharma V, Kamal B, Srivastava N, Dobriyal AK, Jadon VS (2013) Effects of additives in shoot multiplication and genetic validation in Swertica chirayita revealed through RAPD analysis. Plant Tissue Cult Biotechnol 23(1):11-19 